\title{
ANTIFUNGAL POTENTIAL AND PHYTOCHEMISTRY OF Tetrapterys multiglandulosa CAV AERIAL PARTS
}

\author{
POTENCIAL ANTIFÚNGICO E FITOQUIMMICA DAS PARTES AÉREAS DE \\ Tetrapterys multiglandulosa $C A V$
}

\section{Gilberto Gonçalves FACCO ${ }^{1}$; Jéssica de A. Isaias MULLER ${ }^{2}$; Rosemary MATIAS ${ }^{3}$; Marcos BARBOSA-FERREIRA ${ }^{4}$; Bianca Obes CORREA ${ }^{4}$; José Antônio Maior BONO ${ }^{4}$; Doroty Mesquita DOURADO ${ }^{2}$; Carlos Eurico dos Santos FERNANDES ${ }^{5}$}

1. Aluno do Curso de Pós-Graduação em Ciência Animal da Faculdade de Medicina Veterinária e Zootecnia-FAMEZ, Universidade Federal do Mato Grosso do Sul - UFMS, Campo Grande, MS, Brasil. gilbertogfacco@ hotmail.com; 2. Programa de Pós Graduação em Doenças Infecciosas e Parasitárias - UFMS, Campo Grande, MS, Brasil; 3. Programa da Pós Graduação em Meio Ambiente e Desenvolvimento Regional, Universidade Anhanguera - Uniderp, Campo Grande, MS, Brasil; 4. Programa de Pós Graduação, Mestrado Profissional em Produção e Gestão Agroindustrial, Universidade Anhanguera - Uniderp, Campo Grande, MS, Brasil; 5. Professor, Doutor, FAMEZ - UFMS, Campo Grande, MS, Brasil.

\begin{abstract}
Tetrapterys spp. are considered toxic to grazing animals owing to the presence of a poisonous constituent cardiotonic glycoside. However, other chemicals within the plant have allelopathic, bactericidal, and fungicidal activities. The objective of this study was to search for natural products as alternatives in the control of plant pathogenic fungi, which diminish the crop productivity and cause damage to animal and human health. The phytochemical content of the stems and leaves was investigated alongside the fungitoxic potential of aqueous and ethanol extracts from aerial parts of T. multiglandulosa on Fusarium moniliforme and F. graminearum. The leaves and stems were obtained from 20 arrays of T. multiglandulosa from Batayporã City, south of Mato Grosso do Sul, and classified as young and mature. The botanical material was oven dried, crushed, and its aqueous and $20 \%$ ethanol extracts were used for qualitative and quantitative phytochemical assays. For in vitro tests of fungal growth inhibition, extract concentrations of 200, 400, 800, 1600 , and $2000 \mu \mathrm{g} \mathrm{L}^{-1}$ were assayed, with two control groups. Phytochemical tests from aqueous and ethanol extracts of young and mature leaves indicated the presence of phenolic compounds, tannins, flavonoids, saponins, alkaloids, and cardiotonic glycosides. The aqueous extract of young leaves showed potential fungicidal activity against $F$. graminearum, with values ranging from $21.25 \%$ to $33.53 \%$ colony growth inhibition.
\end{abstract}

KEYWORDS: Malpighiaceae. Secondary metabolites. Afrosimetric index.

\section{INTRODUCTION}

The Malpighiaceae family has about 70 genera and 1300 species, and half of these species are found in Brazil. The main phytochemicals of the Malpighiaceae family are carboline alkaloids, simple indole bases, phenylpropanoids, flavonoids, triterpenoids, and polysaccharides in various genera (SOUZA; LORENZI, 2008). Recent studies have recorded the plant occurrence in different biomes spread throughout Brazil, such as Caatinga, Campinarana, Campo Limpo, Campo Rupestre, Carrasco, Cerrado, riparian forest or gallery, land forest firm, lowland forest, semi-deciduous forest, rainforest, and vegetation on rocky outcrops (FLORA DO BRASIL 2020, 2016). Tetrapterys spp. are toxic to domestic animals, especially $T$. multiglandulosa A. Juss., a plant known to cause toxicity in cattle and sheep. It grows mainly in southeastern Brazil, known by the common names "cipó-vermelho" and "cipó-ferro" (TOKARNIA et al., 2000). A recent outbreak of cattle poisoning caused by grazing in a $T$. multiglandulosa infested area at the borderline of a semi-deciduous forest (Cerradão forest) in Mato Grosso do Sul, CentralWestern region, was reported (CARVALHO et al., 2006).

The leaves are the toxic part of the plant and contain condensed tannins, quaternary alkaloids, flavonic glycosides, steroids, and cardiotonic glycosides among other chemicals (MELO et al., 2001). Cardiotonic glycosides are steroidal saponins and triterpenes, and this class of substances has been associated with sudden death due to congestive heart failure (ALMEIDA et al., 2008; TOKARNIA, 2002). Despite the related poisoning of livestock, the search for natural substances to control fungal infection has been intensified due to the efficiency and economy of these products in controlling pathogens and pests in place of chemical pesticides (RODRIGUES, 2002; VENTUROSO et al., 2011). The phytochemicals present in this weed can interfere with the action or the development of several fungi that attack crops.

Pathogenic fungi can decrease productivity and quality of agricultural products. If they are 
present in raw foodstuffs, such as corn and wheat, pathogenic fungi may threaten human health (RHEEDER et al., 2002). The presence of fungi in corn can produce mycotoxins that cause disease in horses, pigs, and poultry and cancer in humans (BEZUIDENHOUT et al., 1988; ROSS et al., 1991; WEIBKING et al., 1993; NORRED e VOSS, 1994; JULIAN et al., 1995). Fusarium moniliforme Sheldon is one of the key fungi that contaminate the seeds, both in Brazil and in other countries (CASA et al., 1998; GOULART; FIALHO, 1999).

$F$. moniliforme mycotoxins have been found to be present in $80 \%$ of corn samples in Brazil, indicating the need to combat this pathogen (HIROOKA et al., 1996). Fusarium spp. are also found in wheat, particularly $F$. graminearum, $F$. culmorum, and $F$. avenaceum, causing Fusariosis, (CALORI-DOMINGUES et al., 2007), which is considered one of the major diseases of wet regions in Brazil (PANISSON et al., 2002; CASA et al., 2004; CALORI-DOMINGUES et al., 2007). The presence of mycotoxins is associated with symptoms of acute illnesses such as nausea, vomiting, dizziness, gastrointestinal problems, and diarrhea; thus, in crops of corn and wheat, the presence of these pathogenic fungi can reduce productivity and cause damage to animal and human health, in addition to being difficult to control (CASA et al., 2004).

The control or inhibition the growth of Fusarium spp. in such grains is a challenge because of the ease of its propagation in crops or in storehouses under damp conditions. Therefore, these studies are crucial to discover whether plant chemical compounds are efficient in controlling fungal growth and could be an alternative for pesticides that contaminate the environment. Thus, the objective of this study was to perform a phytochemical analysis of T. multiglandulosa aerial parts and investigate the fungitoxic potential of its aqueous and ethanol extracts on $F$. moniliforme and F. graminearum.

\section{MATERIAL AND METHODS}

The leaves and stems were obtained from 20 arrays of T. multiglandulosa collected from São Pedro Farm, Batayporã City, Mato Grosso do Sul, ( $27^{\circ} 31^{\prime} 71^{\prime \prime}$ South and $\left.74^{\circ} 95^{\prime} 99^{\prime \prime} \mathrm{W}\right)$ in November 2011, and transported to the Plant Morphology laboratory at the Anhanguera-Uniderp University, Campo Grande City, Mato Grosso do Sul. The samples of specimens were deposited in the Institution's herbarium under the voucher number 8022.

\section{Leaves and stem phytochemistry}

Each concentration of the extract used had three replications for each of the two quantifications. The young and mature leaves and stems of T. multiglandulosa, were cleaned, dried in an oven circulating air at $40{ }^{\circ} \mathrm{C}$ (MARCONI ${ }^{\circledR}$, MA35), and finely ground and separated in a Wiley mill (MARCONI ${ }^{\circledR}$, MA048). Two extracts were obtained from the samples, one aqueous (distilled water) and other ethanolic at a concentration of 200 $\mathrm{g} \mathrm{L}^{-1}(20 \%)$. The extracts were prepared separately using an ultrasound bath (ultrasonic Cleaner ${ }^{\circledR}$ ) for 60 minutes followed by soaking for 24 hours. This procedure was repeated for two consecutive days and the extracts were subsequently filtered (glass funnel and cotton) in a volumetric flask.

The water and ethanol extracts were submitted to phytochemical assays for phenolic compounds, tannins, flavonoids, free coumarins, anthocyanins, anthraquinone, steroids, triterpenes, alkaloids, saponins, cyanogenic glycosides, and cardiotonic heterosides. Analyses were performed in triplicate following methodology adapted by Matos (2009).

Within the assays, alterations in color and/or precipitation were compared with the control (Fontoura et al., 2015), as being strongly positive $(+++)$, moderately positive $(++)$, weakly positive $(+)$, and partially positive $( \pm)$; however, where there was only haze and/or partially changed color, or the absence of color and/or precipitation, it was considerate as negative (-). The intensity of color and/or precipitation indicates the increased concentration of such class of secondary metabolite.

\section{Afrosimetric index \\ To estimate the presence of saponin in leaves and stems, the foam test (afrosimetric testing), adapted from Costa (2002), was performed. \\ Characterization reactions for cardiotonic glycosides}

The presence of cardiotonic glycosides was determined using the Baljet reaction that characterizes the presence of unsaturated lactone rings. The presence of a steroidal nucleus, unsaturated lactone in $\mathrm{C}-17$, and deoxy sugars was detected through the reactions of Keller-Killiani and Liebermann-Burchard (SIMÕES et al., 2010).

\section{Total phenol and flavonoid determination}

The water and alcohol extracts were obtained from young and mature leaves by exhaustive soaking at temperatures ranging from 27 to $30{ }^{\circ} \mathrm{C}\left( \pm 2{ }^{\circ} \mathrm{C}\right)$ over a period of 10 days. The 
extracts were dried under reduced pressure in a rotary evaporator $\left(\right.$ Marconi $\left.^{\circledR}\right)$ and total phenol content was determined by the Folin-Ciocalteu method using $100 \mathrm{mg}$ of each extract. Analyses were performed using gallic acid as the standard (SAE 10 to $300 \mu \mathrm{g} \mathrm{L}^{-1}$ ) for the calibration curve ( $\mathrm{y}=$ $\left.0.1435+0,01314 x ; R^{2}=0.9988\right)$; the measurements were performed using a spectrophotometer in quartz cuvettes at $750 \mathrm{~nm}$ (SOUSA et al., 2007).

The quantification of flavonoids in water and ethanol extracts (100 $\mathrm{mg}$ ) was performed under the methodology described by Peixoto Sobrinho et al. (2008) using quercetin as the standard $(\mathrm{QE}=\mathrm{PQ}$ $\left.0.5 \mathrm{mg} \mathrm{mL}^{-1}\right)$ to construct the calibration curve ( $\mathrm{y}=$ $\left.0,0875 x+0.0958 ; R^{2}=0.9972\right)$. The samples were analyzed in a spectrophotometer at a wavelength of $420 \mathrm{~nm}$, in quartz cuvettes.

\section{In vitro tests of plant extracts to assess fungal growth inhibition}

The experimental design followed a completely randomized factorial scheme with two factors, represented by extracts at different concentrations, with four replications for each assay.

An aliquot of each aqueous and ethanol extract was added separately to the potato-dextroseagar (BDA) culture medium, so that they obtain concentrations of 200;400;8000; 1600, and 2000 $\mu \mathrm{g} \mathrm{L}^{-1}$ medium, the same being poured into Petri dishes of $90 \mathrm{~mm}$ in a volume corresponding to 10 $\mathrm{mL}$ per plate. After solidification, a mycelium disc of $5 \mathrm{~mm}$ diameter was taken from young colonies of fungi $F$. moniliforme and $F$. graminearum and placed in the center of each separated plate.

Two control groups were used, one prepared in Petri dish containing just BDA and the mycelial disc and the other containing BDA medium supplemented with $5 \mu \mathrm{L}$ of dimethyl sulfoxide (DMSO) solution and $100 \mathrm{~mL}$ of $20 \%$ hydroalcoholic solution at concentration of $2000 \mu \mathrm{g}$ $\mathrm{mL}^{-1}$. All the Petri dishes were incubated in Biochemical Oxygen Demand (BOD) at $22 \pm 2{ }^{\circ} \mathrm{C}$ and were evaluated when the mycelial growth reached the edge of the plate.

The percentage of growth inhibition (PIC) for each sample was calculated from the amount of mycelial growth and was compared with that of the control (MENTEN et al., 1976):

PIC $=\begin{gathered}\text { control diameter }- \text { treatament diameter } \\ \text { control diameter }\end{gathered} \times 100$

The mean levels of phenolic and flavonoid compounds from aqueous and ethanol extracts were evaluated statistically by analysis of variance (ANOVA, $\mathrm{P} \leq 0.05)$, followed by Tukey $(\mathrm{P} \leq 0.05)$; the same procedure was followed for determination of the afrosimetric index.

Regression analysis, correlated to PIC and concentration of the aqueous and ethanol extracts of the plant, was performed. The PIC data were evaluated by ANOVA $(\mathrm{P} \leq 0.05)$. All tests were performed using SAS software (Version 9.2; SAS Institute, Cary, NC).

\section{RESULTS AND DISCUSSION}

The results of the extracts from the phytochemical study of $T$. multiglandulosa indicated that there were significant differences $(\mathrm{P} \leq 0.05)$ in the intensity and variability of secondary metabolite classes (Table 1).

Table 1. Phytochemical study of $T$. multiglandulosa aqueous and ethanol extracts from leaves and stems (young and mature)

\begin{tabular}{|c|c|c|c|c|c|c|c|c|}
\hline \multirow{2}{*}{ Secondary metabolite } & \multicolumn{4}{|c|}{ Aqueous extract $\left(200 \mu \mathrm{g} \mathrm{L}^{-1}\right)$} & \multicolumn{4}{|c|}{ Ethanol extract $\left(200 \mu \mathrm{g} \mathrm{L}^{-1}\right)$} \\
\hline & YL & ML & YS & MS & YL & ML & YS & MS \\
\hline Phenolic compounds & +++ & +++ & +++ & +++ & +++ & +++ & +++ & +++ \\
\hline Tannins & + & + & ++ & +++ & +++ & +++ & ++ & +++ \\
\hline Flavonoids & \pm & \pm & ++ & + & +++ & +++ & + & + \\
\hline Anthocyanins & ++ & ++ & ++ & + & - & - & + & - \\
\hline Free Anthraquinone & + & + & - & + & - & - & - & + \\
\hline Coumarins & + & + & + & - & + & + & + & - \\
\hline Steroids & - & - & + & + & + & + & + & + \\
\hline Triterpens & - & - & + & + & - & - & + & + \\
\hline Alkaloids & + & + & + & - & + & + & + & - \\
\hline Saponins & + & + & + & + & ++ & + & + & + \\
\hline Cardiotonic Heterosides & ++ & + & + & + & ++ & + & + & + \\
\hline
\end{tabular}

YL: Young leaves; ML: mature leaves; YS: Young stem; MS: mature stem; Tests: strongly positive (+++), moderate positive (++), weakly positive (+), partially positive ( \pm ) and negative (-). 
The phenolic compounds, tannins, flavonoids, and cardiotonic glycosides were present in any extract from young and mature leaves and stems. The Malpighiaceae family is commonly associated with terpenoids and essential oils, alkaloids, phenolic, polyphenols and quinone substances, flavonoids, flavonols and flavones, coumarins, and tannins (SOUZA; LORENZI, 2012). Specifically, young and mature fresh leaves of $T$. multiglandulosa were linked to the presence of flavonic glycosides and steroids, meanwhile condensed tannins and quaternary alkaloids were found only in mature leaves (MELO et al., 2001).

Anthocyanins were detected with greater intensity in aqueous extract independently of the plant part and the maturation stage. Although the concentration of anthocyanins tends to be high in young tissues, leaves of different stages of maturation can present it because abiotic factors that lead to different stresses (GITELSON et al., 2001) as well as protection of the leaves against excessive light or UV radiation and against predation contribute to the production of these pigments (SIMS; GAMON, 2002). So anthocyanins features act as natural fungicides (VIZCANO et al., 2007).

The same diversity of secondary metabolites had not been reported in other genera of this family. Rodríguez et al. (2008) detected monoterpenoids, alkaloids, and saponins in the aqueous extract of leaves and stems of fresh $T$. styloptera and monoterpenoids, alkaloids, saponins, and triterpenes in the ethanol extract of leaves and stems of fresh $T$. styloptera, while monoterpenoids and alkaloids were detected in aqueous extract of T. mucronata and the monoterpenes in the ethanol extract $T$. mucronata.

The presence of secondary metabolites may vary in quantity and quality from species to species, and are dependent on biotic and abiotic factors such as the age of the plant tissue, temperature, light intensity, availability of nutrients, microbial activity of rhizosphere, composition of the soil, etc. (FERREIRA; ÁQUILA, 2000). In relation to physiological factors such as photosynthesis, stomatal behavior, mobilization of reserves, leaf expansion, and tissue growth, secondary metabolites are impacted by conditions such as environmental stress that can lead to changes in the plant biosynthetic pathway. Such changes in secondary metabolism induce the production of defense substances as responses to changes in the plant habitat (SALISBURY; ROSS, 1991). In this way, Marqui et al. (2008) reported the saponin triterpene action against human pathogens and against phytopathogenic fungi Cladosporium cladosporioides and C. sphaerospermum.

As stated Gobbo-Neto e Lopes (2007), in most cases, new tissues have a higher rate of production of metabolites. In the present paper, besides qualitative analyzes, the quantitative analysis showed that young leaves and stems had statistically significantly $(\mathrm{P} \leq 0.05)$ higher levels of phenolic compounds in aqueous and ethanol extract compared to mature leaves and stems. Regarding flavonoids, a similar result occurred in analyses of the aqueous extract of young and mature stems from double extracts. In contrast to phenolic compounds, mature leaves have higher $(\mathrm{P} \leq 0.05)$ concentrations of flavonoids than the young leaves in aqueous extract and are equal to concentrations found in the alcoholic extract (Table 2).

Afrosimetric index revealed that the mature leaves have a higher concentration of saponins $(\mathrm{P} \leq$ $0.05)$ than the young leaves. Young and mature stems showed no statistically significant difference between them and had lower index values $(\mathrm{P} \leq 0.05)$ than the mature leaves. This test, also called foam index, is a semi-quantitative saponin evaluation recommended by National Health Surveillance Agency - ANVISA (BRASIL, 2009), which states that the herbal drugs used by humans, for example, teas, have to be a value below 100 . The foam index indicates the high toxicity of leaves and stems in the study. Saponins are a particular group of glycosides having a steroidal or triterpene core with nonpolar characteristics linked to a polar portion (the glucides). It has toxic effects on animals such as those observed for protodioscin and digoxin on humans and animals (TOKARNIA et al.; 2000; OLIVEIRA, 2013). Saponins reduce water surface tension, which enhances their functions as detergents and emulsifiers (SIMÕES et al., 2010), allowing saponins to penetrate the fungus cell membrane and leading to leakage of cell content (BARILE et al., 2007).

In the in vitro tests against $F$. moniliforme, the lowest PIC was observed regardless of the concentration and extract type - the highest inhibition rate was $8.08 \%$ - meanwhile for $F$. graminearum, the two extracts in different concentrations gave inhibitions of the fungus growth. The aqueous extract of young leaves have the greatest PIC, at a concentration of $2000 \mu \mathrm{g} \mathrm{mL}^{-1}$, leading to an inhibition of $33.4 \%$. Meanwhile the ethanol extract of young stems gave the best dose response of PIC (ANOVA<0,001; $\mathrm{R}^{2}=0.94$ ) as shown at Figure 1 . Thus, one can observe that different parts of T. multiglandulosa could be used 
for extracting because leaves and stems have a broad spectrum of phytochemicals.

Table 2. Levels of phenolic (PC) and flavonoid (Fl) compounds from aqueous and ethanol extracts of leaves and stems (young and mature), and afrosimetric index of dry extract of Tetrapterys multiglandulosa leaves and stems. Data of PC and Fl are presented as means and its standard error

\begin{tabular}{|c|c|c|c|c|}
\hline \multirow[b]{3}{*}{ Secondary metabolite } & \multicolumn{4}{|c|}{ T. multiglandulosa Aqueous extract $\left(200 \mu \mathrm{g} \mathrm{L}^{-1}\right)$} \\
\hline & \multicolumn{2}{|c|}{ Leaves } & \multicolumn{2}{|c|}{ Stems } \\
\hline & Young & Mature & Young & Mature \\
\hline $\mathrm{PC} \mathrm{mg} \mathrm{g}^{-1}$ (mg gallic acid) & $77.6_{a} \pm 0.04$ & $74.5_{c} \pm 0.03$ & $75.3_{\mathrm{b}} \pm 0.05$ & $73.2_{\mathrm{d}} \pm 0.04$ \\
\hline \multirow[t]{3}{*}{ Fl mg g $\mathrm{mg}^{-1}$ (mg quercetin) } & $35.5_{c} \pm 0.05$ & $44.4_{\mathrm{a}} \pm 0.10$ & $39.9_{b} \pm 0.60$ & $33.36_{c} \pm 0.03$ \\
\hline & \multicolumn{4}{|c|}{ T. multiglandulosa alcoholic extract $\left(200 \mu \mathrm{g} \mathrm{L}^{-1}\right)$} \\
\hline & \multicolumn{2}{|c|}{ Leaves } & \multicolumn{2}{|c|}{ Stems } \\
\hline Secondary metabolite & Young & Mature & Young & Mature \\
\hline PC $\mathrm{mg} \mathrm{g}^{-1}$ (mg gallic acid) & $87.8_{\mathrm{a}} \pm 0.04$ & $80.1_{d} \pm 0.03$ & $85.8_{\mathrm{b}} \pm 0.06$ & $83.1_{\mathrm{c}} \pm 0.03$ \\
\hline \multirow[t]{3}{*}{ Fl $\mathrm{mg} \mathrm{g}^{-1}$ (mg quercetin) } & $21.9_{\mathrm{a}} \pm 0.04$ & $23.5_{\mathrm{a}} \pm 0.04$ & $10.6_{b} \pm 0.04$ & $7.4_{c} \pm 0.04$ \\
\hline & \multicolumn{4}{|c|}{ T. multiglandulosa dry extract } \\
\hline & \multicolumn{2}{|c|}{ Leaves } & \multicolumn{2}{|c|}{ Stems } \\
\hline \multirow[t]{2}{*}{ Afrosimetric index } & Young & Mature & Young & Mature \\
\hline & $1111.1_{\mathrm{c}}$ & $1428.6_{a}$ & $1250.0_{\mathrm{b}}$ & $1250.0_{\mathrm{b}}$ \\
\hline
\end{tabular}

Different letters in same line have significant differences (ANOVA, $\mathrm{P} \leq 0.05)$ followed by Tukey $(\mathrm{P} \leq 0.05)$. PC: Fenolcompound; Fl: Flavonoids

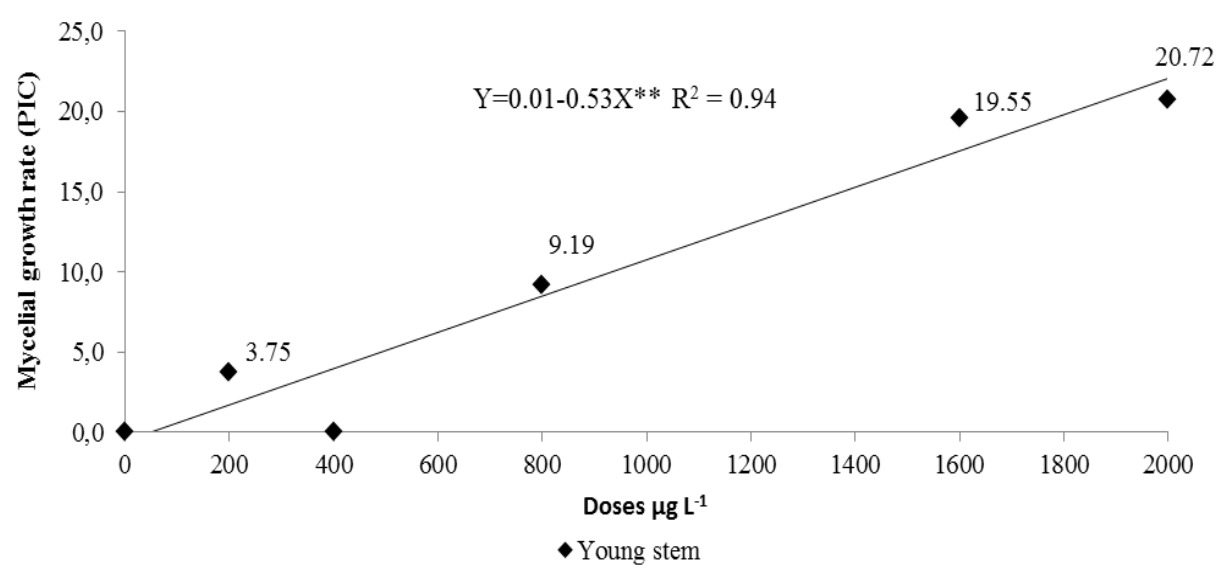

Figure 1. In vitro mycelial percentage of growth inhibition (PIC) of Fusarium graminearum against directly ethanol extracts of young stems of Tetrapterys multiglandulosa. ANOVA $<0.05$, followed by linear regression test. $* * \mathrm{P}<0.001$.

Among the chemicals that play an important role in plant defense to attack fungi are flavonoids and tannins (ZUANAZZI, 2002; AGRIOS, 2005), which also have antibacterial and antiviral activity (LO; NICHOLSON, 2008). In this study, they were identified on a larger scale in ethanol extracts from young and mature leaves. The cardiotonic heterosides compounds and saponins found in all extracts of this work are phytochemicals capable of inhibiting the development of pathogens or creating adverse conditions for the survival of these pathogens in host tissues (SCHWAN-ESTRADA et al., 2008), a fact that could contribute to the use of these extracts in the treatment of plant diseases. Additionally, the ethanol extract had higher activity than the aqueous extract independent of the plant part. The enhanced activity may be related to the high content of phenolic compounds in ethanol extracts. According to Stangarlin et al. (2011), the secondary metabolites present in the extracts can act in inhibiting the germination of fungi spores and mycelial growth and in the production or activity of 
microbial enzymes, making them act on the biochemical and structural mechanisms of plant resistance to pathogen attack.

However, further studies are necessary to continue this work in seeking the development of a prototype compound or molecule template for the synthesis of new fungicides, starting from fractions of extracts of this plant.

\section{CONCLUSIONS}

The ethanolic extract of young stems have the potential to study and develop new approaches to control $F$. graminearum.

The antifungal potential is likely to be related to the chemical constitution of plant, which has a large amount of secondary metabolites, such as flavonoids and phenolic compounds.

RESUMO: As espécies do gênero Tetrapterys são consideradas plantas tóxicas para animais de pastagem e um dos constituintes químicos responsáveis por estas intoxicações são os heterosideos cardiotônicos os quais também possuem atividade alelopática, bactericida, fungicida, dentre outras. Estes fatos e a busca por produtos naturais que possam ser empregados na agricultura familiar, como uma alternativa, no controle fungos fitopatogênicos que além de diminuir a produtividade podem causar danos à saúde animal e humana nos levou a investigar o potencial fungitóxico do extrato aquoso e etanólico das partes aéreas de Tetrapterys multiglandulosa sobre Fusarium moniliforme e $F$. graminearum e a determinar os fitoconstituintes. As folhas e caules foram obtidas de 20 matrizes de T. multiglandulosa na região de Batayporã, Mato Grosso do Sul e classificadas em jovens e adultas. O material botânico foi seco em estufa, triturado e os extratos aquoso e etanólico a $20 \%$ submetidos aos ensaios fitoquímicos quali e quantitativos. No teste in vitro de atividade de inibição de crescimento fúngico os extratos foram diluídos nas concentrações de 200, 400, 800,1600 e $2000 \mu \mathrm{g} \mathrm{mL}^{-1}$ utilizando-se duas testemunhas. Testes fitoquímicos a partir de extratos aquosos e etanólicos de folhas e caules novos e maduros indicou a presença de compostos fenólicos taninos, flavonóides, alcalóides, saponinas e glicósideos cardiotônicos. O extrato aquoso das folhas jovens apresentou maior potencial fungicida contra F. graminearum com $33,53 \%$ de inibição de crescimento da colônia.

KEYWORDS: Fitoconstituintes. Inibição de crescimento. Compostos fenólicos. Plantas tóxicas.

\section{REFERENCES}

AGRIOS, G. N. Plant Pathology. Academic press, San Diego, 5. ed. p. 803, 2005.

ALMEIDA, M. B.; PRIEBE, A. P. S.; RIET-CORREA, B.; RIET-CORREA, G.; FISS, M. B.; SCHILD, A. L. Evolução e reversibilidade das lesões neurológicas e cardíacas em ovinos intoxicados experimentalmente por Ateleia glazioviana e Tetrapterys multiglandulosa. Pesquisa Veterinária Brasileira, Rio de Janeiro, v. $28, \mathrm{n}$. 03, março de 2008. http://dx.doi.org/10.1590/S0100-736X2008000300001.

BARILE, E.; BONANOMI, G.; ANTIGNANI, V.; ZOLFAGHARI, B.; EBRAHIM SAJJADI, S.; SCALA, F.; LANZOTTI, V. Saponins from Allium minutiflorum with antifungal activity. Phytochemistry, Washington, v. 68, 596-603, 2007. http://dx. doi:10.1016/j.phytochem.2006.10.009.

BEZUIDENHOUT, G. C.; GELDERBLOM, W. C. A.; GORST-ALLMAN, C. P.; HORAK, R. M.; MARASAS, W. F. O.; SPITELLER, G.; VLEGAAR, R. Structure elucidation of the fumonisins, mycotoxins from Fusarium moliniforme. Journal of the Chemical Society, chemical communications, Com. 1476, p. 734745. 1988. http://dx.doi: 10.1039/C39880000743.

BRASIL, 2009. Ministério da Saúde. Agência Nacional de Vigilância Sanitária. Resolução RDC no. 38, de 22 de Junho de 2009. Determina a atualização e revisão periódica da Farmacopéia Brasileira. DOU. Poder Executivo, Brasília, DF, 22 jun. 2009.

CALORI-DOMINGUES, M. A.; ALMEIDA, R. R.; TOMIWAKA, M. M.; GALLO, C. R.; GLORIA, E. M.; DIAS, C. T. S. Ocorrência de desoxinivalenol em trigo nacional e importado utilizado no Brasil. Ciência Tecnologia de Alimentos, Campinas, v. 27, n. 01, Jan-Mar. 2007. 
CARVALHO, M. N.; ALONSO, L. A.; CUNHA, T. G.; RAVEDUTTI, J.; BARROS, C. S. L.; LEMOS, R. A. A. Intoxicação de bovinos por Tetrapterys multiglandulosa (Malpighiaceae) em Mato Grosso do Sul. Pesquisa Veterinária Brasileira, Rio de Janeiro, v. 26: (3)139-146. 2006.

CASA, R. T.; REIS, E. M.; BLUM, M. M. C.; BOGO, A.; SCHEER, O.; ZANATA, T. Danos causados pela infecção de Gibberella zeaeem trigo. Fitopatologia Brasileira, Brasília, v. 29, n. 3, May-June, 2004. http://dx.doi:org/10.1590/S0100-41582004000300008.

CASA, R.T., ZAMBOLIM, L.; REIS, E. M. Transmissão e controle de diplodia em sementes de milho. Fitopatologia Brasileira, Brasília, v. 23, n. 4, p. 436-441. 1998.

COSTA, A. F. Farmacognosia. 6. ed. Calouste Gulbenkian, Lisboa, 824p. 2002.

FERREIRA, A. G.; ÁQUILA, M. E. A. Alelopatia: uma área emergente da ecofiologia. Revista Brasileira de Fisiologia Vegetal, Campinas, v. 12, n. especial, 2000, p. 175-204.

FLORA DO BRASIL 2020 em construção. Tetrapterys Cav. Jardim Botânico do Rio de Janeiro. Available in: <http://reflora.jbrj.gov.br/reflora/floradobrasil/FB8967>. Acesso em: 05 August 2016.

FONTOURA, F. M.; MATIAS, R.; LUDWIG, J.; OLIVEIRA, A. K. M.; BONO, J. A. M.; MARTINS, P. D. F. R. B.; GUEDES, N. M. R. Seasonal effects and antifungal activity from bark chemical constituents of Sterculia apetala (Malvaceae) at Pantanal of Miranda, Mato Grosso do Sul, Brazil. Acta Amazônica, Manaus, v. 45, n. 3, p. 283-292, 2015. http://dx.doi.org/10.1590/1809-4392201500011.

GITELSON, A. A.; MERZLYAK, M. N.; CHIVKUNOVA, O. B. Optical properties and non-destructive estimation of anthocyanin content in plant leaves. Photochemistry and Photobiology, Canada, v. 74, p. 38-45, 2001.

GOBBO-NETO, L.; LOPES, N. P. Plantas medicinais: fatores de influência no conteúdo de metabólitos secundários. Química Nova, São Paulo, v. 30, n. 2, p. 374-381, 2007.

GOULART, A. C. P.; FIALHO, W. F. B.; FUJINO, M. T. Viabilidade técnica do tratamento de sementes de soja com fungicidas antes do armazenamento. Dourados: EMBRAPA-CPAO, 1999. 41p. (Boletim de Pesquisa, 2).

HIROOKA, E. Y.; YAMAGUCHI, M. M.; AOYAMA, S.; SUGIURA, Y; UENO, Y. The natural occurrence of fumonisins in Brazilian corn kernels. Food Addit Contaminants, United Kingdom, v. 13, n. 2 173-183. 1996.

JULIAN, A. M.; WAREING, P. W.; PHILIPS, S. I.; MEDLOCK, V. F. P.; MACDONALD, M. V.; RÍO, L. E. Fungal contamination and selected mycotoxins in preand postharvest maize in Honduras. Mycopathologia, Netherlands, v. 129, p. 5-16, 1995.

LO, SZE-CHUNG CLIVE; NICHOLSON, R. L.; TREMACOLDI, C. R. (Trad) Compostos fenólios e importância nas doenças em plantas. In PASCHOLATI, S.F; LEITE, B.; STANGARLIN, J. R.; CIA, P. Interação Planta-Patógeno: Fisiologia, Bioquímica e Biologia Molecular. Piracicaba, FEALQ, v. 13, 2008, p. 285-303.

MARQUI, S. R.; LEMOS, R. B.; SANTOS, L. A.; CASTRO-GAMBOA, I.; CAVALHEIRO, A. J.; BOLZANI, V. S.; SILVA, D. H. S. Saponinas antifúngicas de Swartzia langsdorffii. Química Nova, São Paulo, v. 31, n. 4, p. 828-831, 2008.

MATOS, J. F. A. Introdução a Fitoquímica Experimental. 2. ed. Fortaleza: UFC, 2009. 141 p. 
MELO, M. M.; VASCONCELOS, A. C.; DANTAS G. C.; SERAKIDES R.; ALZAMORA FILHO F. Experimental intoxication of pregnant goats with Tetrapterys multiglandulosa A. Juss. (Malpighiaceae). Arquivo Brasileiro de Medicina Veterinária e Zootecnia, Belo Horizonte, v. 53, p. 58-65, 2001. http://dx.doi.org/10.1590/S0102-09352001000100009.

MENTEN, J. O. M.; MINUSSI, C. C.; CASTRO, C.; KIMATI, H. Efeito de alguns fungicidas no crescimento micelial de Macrophomina phaseolina (Tass.) Goid. "in vitro". Fitopatologia Brasileira, Brasília, v. 1, n. 2, p. 57-66, 1976.

NORRED, W. P.; VOSS, K. A. Toxicity and role of fumonisins animal diseases and human esophageal cancer. Journal of Food Protection, Iowa, v. 57, p. 522-527, 1994.

PANISSON, E.; REIS, E. M.; BOLLER, W. Quantificação de propágulos de Gibberella zeae no ar e infecção de anteras em trigo. Fitopatologia Brasileira, Fortaleza, v. 27, n. 5, p. 484-488, 2002.

PEIXOTO SOBRINHO, T. J. S.; SILVA, C. H. T. P.; NASCIMENTO, J. E.; MONTEIRO, J. M.; ALBUQUERQUE, U. P.; AMORIM, E. L. C. Validação de metodologia espectrofotométrica para quantificação dos flavonóides de Bauhinia cheilantha (Bongard) Steudel. Revista Brasileira de Ciências Farmacêuticas, São Paulo, v. 44, n. 4, p. 683-9, 2008. http://dx.doi.org/10.1590/S1516-93322008000400015.

RHEEDER, J. P.; MARASAS, F. O; VISMER, H. F. Production of fumonisin analogs by Fusarium species. Applied and Environmental Microbiology, Washington, DC, v. 68. p. 2101-2105, 2002.

RODRIGUES, A. G. Biodiversidade e etnociência de plantas medicinais da comunidade Miguel

Rodrigues-MG. 210 f., Tese (Doutorado em Fitotecnia) - Universidade Federal de Viçosa, Viçosa, 2002.

RODRÍGUEZ, M.; HASEGAWA, M.; GONZÁLEZ-MÚJICA, F.; MOTTA, N.; CASTILLO A.; CASTILLO, J.; MORA, E. Z.; KIBY, L. S.; GONZÁLEZ; A.; CAMEJO, D. Antidiabetic and antiradical activities of plants from Venezuelan Amazon. Revista Brasileira de Farmacognosia, Curitiba, PR, v. 18, n. 3, 2008. http://dx.doi.org/10.1590/S0102-695X2008000300004.

ROSS, P. F.; NELSON, P. E.; RICHARD, I. D.; OSWEILLER, G. D.; RICE, L. G.; PLATTNER, R. D.; WILSON, T. M. Production of fumonisins by Fusarium moniliforme and F. proliferatum isolates associated with equine leukoencephalomalacia and pulmonary edema syndrome in swine. Applied and Environmental Microbiology, Washington, v. 56, p. 3225-3226, 1991.

SALISBURY, F. B.; ROSS, C. W. Plant Physiology. 4. ed. Belmont, Wadsworth, 1991. 682 p.

SCHWAN-ESTRADA, K. R. F.; STANGARLIN, J. R.; PASCHOLATI, S. F. Mecanismos bioquímicos de defesa vegetal. In: PASCHOLATI, S. F.; LEITE, B.; STANGARLIN, J. R. \& CIA, P. (Org.). Interação planta-patógeno: fisiologia, bioquímica e biologia molecular. Piracicaba, SP: Fealqcap. p. 227-248, 2008.

SIMÕES, C. M. O.; SCHENKEL, E. P.; GOSMAN. G.; MELLO. J. C. P.; MENTZ, L. A.; PETROVICK. Farmacognosia: da planta ao medicamento. 6. ed. Porto Alegre: Editora UFRGS, 2010. 1102 p.

SIMS, D. A.; GAMON, J. A. Relationships between leaf pigment content and spectral reflectance across a wide range of species, leaf structures and developmental stages. Remote Sensing of Environment, New York, v. 81, p. 337-354, 2002. http://PII: S0034-4257(02)00010-X.

SOUSA, C. M. M. S.; SILVA, H. R.; VEIERA-JR, G. M.; AYRES, M. C. C.; CHARLLYTON, L. S. C.; DELTON, S. A.; CAVALCANTE, L. C. D.; BARROS, E. D. S.; ARAUJO, P. B. M.; BRANDRÃO, M. S.; CHAVES, M. H. Fenóis totais e atividade antioxidante de cinco plantas medicinais. Química Nova, São Paulo, v. 30, n. 2, p. 351-355, 2007. http://dx.doi.org/10.1590/S0100-40422007000200021. 
SOUZA, V. C.; LORENZI, H. Botânica Sistemática: guia ilustrado para identificação das famílias de Fanerógamas nativas e exóticas no Brasil, baseado em APG III. 3. ed. Nova Odessa - SP: Instituto Plantarum, 2012. 768 p.

STANGARLIN, J. R.; KUHN, O. J.; ASSI, L.; SCHWAN-ESTRADA, K. R. F. Control of plant diseases using extracts from medicinal plants and fungi. In: MÉNDEZ-VILAS A. (ed.). Science against microbial pathogens: communicating current research and technological advances. Badajoz: Formatex. v. 2, 2011. p.1033-1042.

TOKARNIA, C. H.; DOBEREINER, J.; PEIXOTO, P. V. Plantas tóxicas do Brasil, 1. ed. Rio de Janeiro: Ed. Helianthus, 2000. 320 p.

TOKARNIA, C. H.; DOBEREINER, J.; PEIXOTO, P. V. Poisonous plants affecting livestock in Brazil. Toxicon, United Kingdom, v. 40, n. 12, p. 1635-1660, 2002.

VENTUROSO, L. R.; BACCHI, L. M. A.; GAVASSONI, W. L.; CONUS, L. A.; PONTIM, B. C. A.; BERGAMIN, A. C. Atividade antifúngica de extratos vegetais sobre o desenvolvimento de fitopatógenos. Summa Phytopathologica, Botucatu, v. 37, n. 1, p. 18-23, 2011. http://dx.doi.org/10.1590/S010054052011000100003.

VIZCANO, R. L. M.; DE LA ROSA TORRES, C.; PÉREZ, A. M. Actividad antifungica del extracto total en etanol de la hojas frescas de Pedilanthus tithymaloides L poit (ultimorrial). Scientia et Technica, Colombia, v. 1, n. 33, p. 155-159, 2007. http://revistas.utp.edu.co/index.php/revistaciencia/article/viewFile/6171/3201.

WEIBKING, T. S.; LEDOUX D. R.; BERMUDEZ. A. J.; TURK, J. R.; ROTTINGHAUS, G.E. Effects of feeding Fusarium moniliforme culture material containing know levels of fumonisin B1 on the young broiler chick. Poultry Science, Oxford, 1993, v. 72, p. 456-466.

ZUANAZZI, J. A. S. Flavonóides. In: SIMÕES, C. M. O.; SCHENKEL, E. P.; GOSMANN, G.; MELLO, J. C. P.; MENTZ, L. A.; PETROVICK, P. R. Farmacognosia: da planta ao medicamento. 4. ed. Porto Alegre: Editora da UFRGS; Florianópolis: Editora da UFSC, 2002. 